\title{
Correction to: Lymphocyte subset abnormalities in early diffuse cutaneous systemic sclerosis
}

\author{
David A. Fox ${ }^{1 *}$, Steven K. Lundy ${ }^{1}$, Michael L. Whitfield ${ }^{2}$, Veronica Berrocal ${ }^{3,4}$, Phillip Campbell', \\ Stephanie Rasmussen ${ }^{1}$, Ray Ohara ${ }^{1}$, Alexander Stinson ${ }^{1}$, Mikel Gurrea-Rubio ${ }^{1}$, Evan Wiewiora ${ }^{4}$, Catherine Spino ${ }^{4}$, \\ Erica Bush ${ }^{1}$, Daniel Furst ${ }^{5}$, Shiv Pillai ${ }^{6}$ and Dinesh Khanna ${ }^{1}$
}

\section{Correction to: Arthritis Res Ther (2021) 23:10 https://doi.org/10.1186/s13075-020-02383-w}

Following publication of the original article [1], the authors reported errors in the affiliation of authors Michael L. Whitfield, Veronica Berrocal, Evan Wiewiora and Catherine Spino, and an additional affiliation was added for author Veronica Berrocal. The correct affiliations are as follows:

Michael L. Whitfield should be affiliated to "Department of Biomedical Data Science, Geisel School of Medicine at Dartmouth, Hanover, USA".

Evan Wiewiora and Catherine Spino should be affiliated to "Department of Biostatistics, University of Michigan, Ann Arbor, USA".

Veronica Berrocal should be affiliated to "Department of Biostatistics, University of California, Irvine, CA, USA" and "Department of Biostatistics, University of Michigan, Ann Arbor, USA

The original article has been corrected.

\section{Author details}

'Division of Rheumatology, Department of Internal Medicine, Scleroderma Program, Clinical Autoimmunity Center of Excellence, University of Michigan, Ann Arbor, MI, USA. ${ }^{2}$ Department of Biomedical Data Science, Geisel School of Medicine at Dartmouth, Hanover, USA. ${ }^{3}$ Department of Biostatistics, University of California, Irvine, CA, USA. ${ }^{4}$ Department of Biostatistics,

The original article can be found online at https://doi.org/10.1186/s13075020-02383-w.

* Correspondence: dfox@umich.edu

'Division of Rheumatology, Department of Internal Medicine, Scleroderma Program, Clinical Autoimmunity Center of Excellence, University of Michigan, Ann Arbor, MI, USA

Full list of author information is available at the end of the article
University of Michigan, Ann Arbor, USA. ${ }^{5}$ Division of Rheumatology, UCLA, Los Angeles, USA. ${ }^{6}$ Ragon Institute of MIT, MGH and Harvard, 400

Technology Square, Cambridge, MA 02139, USA.

Published online: 04 March 2021

\section{Reference}

1. Fox DA, Lundy SK, Whitfield ML, et al. Lymphocyte subset abnormalities in early diffuse cutaneous systemic sclerosis. Arthritis Res Ther. 2021;23:10 https://doi.org/10.1186/s13075-020-02383-w.

(c) The Author(s). 2021 Open Access This article is licensed under a Creative Commons Attribution 4.0 International License, which permits use, sharing, adaptation, distribution and reproduction in any medium or format, as long as you give appropriate credit to the original author(s) and the source, provide a link to the Creative Commons licence, and indicate if changes were made. The images or other third party material in this article are included in the article's Creative Commons licence, unless indicated otherwise in a credit line to the material. If material is not included in the article's Creative Commons licence and your intended use is not permitted by statutory regulation or exceeds the permitted use, you will need to obtain permission directly from the copyright holder. To view a copy of this licence, visit http://creativecommons.org/licenses/by/4.0/. The Creative Commons Public Domain Dedication waiver (http://creativecommons.org/publicdomain/zero/1.0/) applies to the data made available in this article, unless otherwise stated in a credit line to the data. 